Herzschr Elektrophys 2013 - 24:139-140

DOI 10.1007/s00399-013-0280-8

Online publiziert: 8. August 2013

(c) Springer-Verlag Berlin Heidelberg 2013
Christian Butter ${ }^{1} \cdot$ Christoph Stellbrink $^{2}$

${ }^{1}$ Abteilung für Kardiologie, Immanuel Klinikum Bernau und Herzzentrum Brandenburg,

Bernau b. Berlin, Deutschland

${ }^{2}$ Klinik für Kardiologie und Internistische Intensivmedizin, Klinikum Bielefeld gGmbH, Bielefeld, Deutschland

\title{
Device-assoziierte Komplikationen
}

\section{Die Elektrode im Focus}

Liebe Leser, liebe Interessierte,

seit ihrer Erstanwendung im Menschen hat die Defibrillatortherapie eine rasante Entwicklung genommen, von der initialen Sekundärprophylaxe hin zur Primärprophylaxe mit steigenden Implantationszahlen. Auch die Versorgung von jungen Patienten mit genetisch bedingten Arrhythmien und erhöhtem Risiko für den plötzlichen Herztod hat zu einer Ausweitung der Indikation geführt.

Dies erfordert eine über Jahrzehnte stabile und sichere technische Performance der implantierten Komponenten, um eine durch das Implantat bedingte Gefährdung der Patienten zu vermeiden.

Die Elektroden, hierbei besonders die technisch wesentlich komplexer aufgebauten ICD-Elektroden, sind als schwächster Teil im System identifiziert worden. Dauernde mechanische Beanspruchungen, ungünstige anatomische Verhältnisse sowie suboptimale Punktionstechniken führen zum Teil zu lebensbedrohlichen Defekten der Elektroden. Auch theoretische Verbesserungen des Sondendesigns haben nicht zwangsweise zu einer längeren Lebensdauer der Elektrode geführt, sondern sogar frühzeitige Recalls nach sich gezogen.

Dramatisch gestiegen sind die Infektionsraten, bedingt durch häufige Gerätewechsel, Upgrades und das sich verändernde ICD-Klientel mit steigender Komorbidität.

Dieses Heft widmet sich dieser Problematik, zeigt den aktuellen Stand der Sondentechnik auf, analysiert aktuelle und historische Defekte und Recalls und dis- kutiert Alternativen. Strategien und klinische Entscheidungsbäume vor geplanter Explantation werden erörtert, Techniken und Tools zur Sondenextraktion geschildert sowie gesondert auf die Erkennung und Therapie Device-assoziierter Infektionen eingegangen. Der aktuelle Stand zur Versorgung mit einem subkutanen ICD ohne transvenöse Elektrode wird erörtert.

Besonderes Augenmerk sollte der Beitrag der EHRA-Arbeitsgruppe zur Sondenextraktion auf sich ziehen. Auf Initiative der EHRA werden erstmals europaweit Sondenextraktionen im gemonitorten ELECTRa-Register erfasst und Rückschlüsse auf institutions- und länderspezifische Unterschiede in der Versorgung von Device-assoziierten Komplikationen analysiert. Von geplanten 3500 einzuschließenden Patienten konnten bereits mehr als 1000 ins Register aufgenommen werden.

Die Auswertung dieser Daten wird in den nächsten Jahren interessante Rückschlüsse erlauben.

Wir wünschen Ihnen viel Freude bei der Lektüre dieses Heftes!

Ihre

PD Dr. Christian Butter

Prof. Dr. Christoph Stellbrink

\section{Dear Colleagues and Readers,}

Since its first clinical application in men in 1980 ICD therapy has been rapidly growing from the initial idea of secondary prevention to primary prevention. Also, the treatment of young patients with genetic electrical disorders with an increased risk for sudden cardiac death has led to an expansion of the indication.

This requires a stable and safe performance of all implanted components over decades to avoid life threatening complications in patients.

The leads, especially the ICD leads, which are more complex and challenging in their structure, have been identified as the weakest part in the whole system. Continuous mechanical stress, unfavourable anatomical findings and suboptimal puncture techniques may lead to lifethreatening defects of the electrodes. Even theoretical improvements in lead design have not always been transferred to an increased longevity of the leads, but required early recalls in some cases.

Device-related infections have been dramatically increased mainly due to repetitive replacements, upgrade procedures and a changing patient population which is increasingly marked by a higher comorbidity.

This issue addresses this problem, shows the current state of lead technology, analyses actual and historic lead problems and recalls and discusses alternatives. Strategies and clinical pathways prior to and post device explantation are discussed, techniques and tools for lead extraction are updated. Furthermore this issue focuses on the detection of device-related infections and their concomitant therapy.

The state-of-the-art of subcutaneous ICD treatment is analyzed, and advantages and disadvantages in comparison 


\section{Editorial}

with transvenous ICD treatment are discussed.

Special attention should be paid to the article about the European Lead Extraction Registry called ELECTRa initiated by the EHRA. It is the first time that Europewide cross-institutional and cross-national monitored data about lead extraction are generated. These data will hopefully allow drawing specific conclusions on device-related complications and treatment. Out of 3500 intended patients to be included already more than 1000 have been registered up to now.

We hope you will enjoy reading this special issue of Herzschrittmachertherapie + Elektrophysiologie.

PD Dr. Christian Butter

Prof. Dr. Christoph Stellbrink

\section{Korrespondenzadressen}

PD Dr. C. Butter
Abteilung für Kardiologie
Immanuel Klinikum Bernau
u. Herzzentrum Brandenburg
Ladeburger Str. 17
16321 Bernau b. Berlin
c.butter@immanuel.de

Prof. Dr. C. Stellbrink
Klinik für Kardiologie und
Internistische Intensivmedizin
Klinikum Bielefeld gGmbH
Teutoburger Strasse 50
33604 Bielefeld
christoph.stellbrink@
klinikumbielefeld.de

